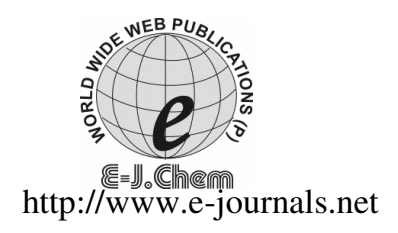

ISSN: 0973-4945; CODEN ECJHAO

E-Journal of Chemistry

2011, 8(2), 671-679

\title{
Corrosion Inhibition of Mild Steel in Acid Solution by 3,4,5-Trimethoxyphenyl-2-imidazolines
}

\author{
D.NALINI ${ }^{*}$, R.RAJALAKSHMI and S.SUBHASHINI \\ "Department of Chemistry \\ PSGR Krishnammal College for Women, Coimbatore-641 004, India \\ Department of Chemistry \\ Avinashilingam University for Women Coimbatore-641 043, India \\ kvkdn@yahoo.com
}

Received 22 August 2010; Accepted 8 November 2010

\begin{abstract}
A heterocyclic imidazoline, 3,4,5-trimethoxyphenyl-2-imidazolines (TMP2I) was tested for its corrosion inhibition in $0.5 \mathrm{M} \mathrm{H}_{2} \mathrm{SO}_{4}$ and $1 \mathrm{M} \mathrm{HCl}$ using weight loss, Tafel polarisation and electrochemical impedance techniques. The results show that the inhibition efficiency increases with the increase in concentration of TMP2I and the higher efficiency of about $98 \%$ is obtained in both the acid media at $20 \mathrm{ppm}$. The adsorption of TMP2I obeys Langmuir adsorption isotherm and occurs spontaneously. Cathodic and anodic polarization curves of mild steel in the presence of different concentrations of TMP2I at $30^{\circ} \mathrm{C}$ reveal that it is a mixed type of inhibitor. Electrochemical impedance studies reveal that the system follows mixed mode of inhibition. The surface morphology of the mild steel specimens was evaluated using SEM images
\end{abstract}

Keywords: Mild Steel, 3,4,5-Trimethoxyphenyl-2-imidazolines, Acid inhibition, Polarisation, EIS , SEM

\section{Introduction}

Corrosion problems have received a considerable amount of attention because of their attack on materials. The use of inhibitors is one of the most practical methods for protection against corrosion. Many researchers have studied the influence of organic compounds containing nitrogen on the corrosion of steel in acid media ${ }^{1-9}$, most organic inhibitors act by adsorption on the metal surface. Corrosion inhibitors function by interfering with either the anodic or cathodic reactions or both. Many of these inhibitors are organic compounds containing nitrogen, sulphur or oxygen atoms or $N$-heterocyclic compounds ${ }^{10}$.

In the present work, we have investigated the inhibitive action of TMP2I on corrosion of mild steel in $0.5 \mathrm{M} \mathrm{H}_{2} \mathrm{SO}_{4}$ and $1 \mathrm{M} \mathrm{HCl}$ using weight loss, Tafel polarisation and electrochemical impedance techniques were carried out. The effects of temperature, immersion time were also studied. Several isotherms were tested for their relevance to describe the adsorption behaviour of the compound studied. 


\section{Experimental}

TMP2I was synthesized using the procedure described by Midori et al. ${ }^{11}$ and the compound was characterized by IR spectral data. IR spectral data shows broad singlet at $3379.65 \mathrm{~cm}^{-1}$ for N-H stretching, aromatic C-H stretching at $2919.96 \mathrm{~cm}^{-1}$, aliphatic stretching at $2827.42 \mathrm{~cm}^{-1}$, $\mathrm{C}=\mathrm{N}$ stretching at $1636.13 \mathrm{~cm}^{-1}$ and for $\mathrm{Ar}-\mathrm{O}-\mathrm{CH}_{3}$ stretching at $1227.62 \mathrm{~cm}^{-1}$. The structure of the TMP2I is shown in the Figure 1.

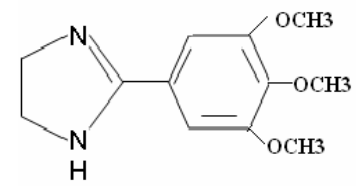

Figure 1. Structure of 3,4,5-trimethoxyphenyl-2-imidazoline

Tests were performed on mild steel having composition (wt.\%) $\mathrm{C}=0.098 \%$, $\mathrm{Mn}=0.201 \%, \mathrm{P}=0.020 \%, \mathrm{~S}=0.016 \%, \mathrm{Ni}=0.012 \%$ and $\mathrm{Fe}=99.653 \%$ used for the measurement of the corrosion rates. Rectangular specimens of working surface area $5 \times 1 \mathrm{~cm}^{2}$ were used for weight loss measurements and $1 \times 1 \mathrm{~cm}^{2}$ with $5 \mathrm{~cm}$ long stem (isolated with Teflon tape) for the electrochemical methods. The specimens were polished mechanically using emery papers and worked thoroughly with triple distilled water, degreased with acetone and dried using air flow at room temperature.

The electrochemical studies were carried out using a three electrode cell assembly at room temperature. Mild steel coupons of $1 \mathrm{~cm} \times 1 \mathrm{~cm}$ (exposed area) were used for electrochemical measurements. Platinum was used as counter electrode and saturated calomel electrode as reference electrode. The electrochemical measurements were carried out using Solartron Electrochemical Analyser Model (1280B). The impedance measurements were carried out in the frequency range of $10 \mathrm{kHz}$ to $10 \mathrm{mHz}$ at the rest potential by applying a $5 \mathrm{mV}$ sine wave ac voltage. The same cell and instrument as in the polarization method were used. The double layer capacitance $(\mathrm{Cdl})$ and charge transfer resistance (Rct) were obtained from Nyquist plots.

\section{Results and Discussion}

The weight loss obtained for the mild steel in different concentrations of sulphuric acid and hydrochloric acid solution is plotted as concentration vs. IE (\%) for various time immersion are shown in Figure 2.
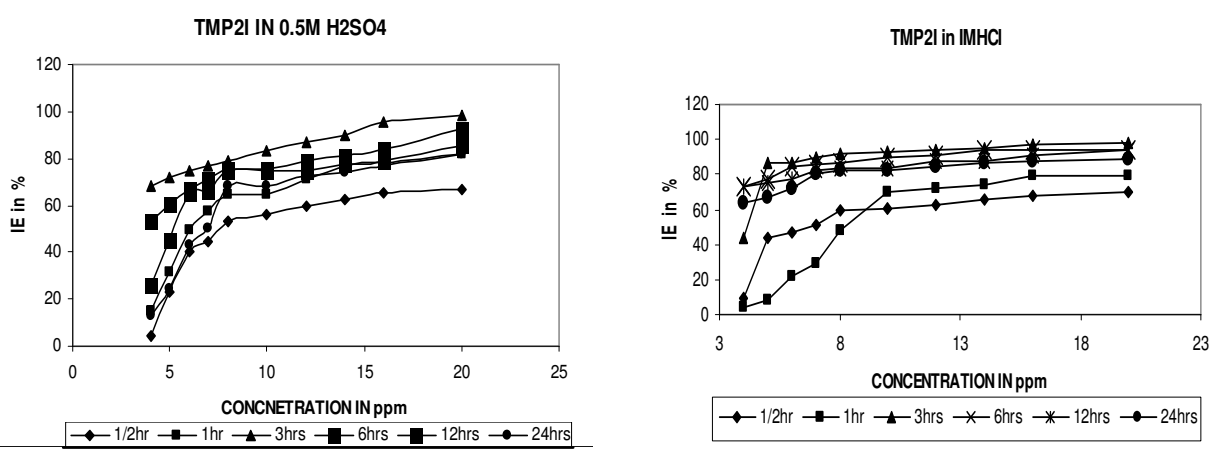

Figure 2. Effect of concentration and immersion time against inhibitor efficiency 
From the Figure it can be seen that the inhibition efficiency increases with increase in concentration of TMP2I which suggest that inhibition is a result of adsorption of inhibitor on the metal surface and TMP2I acts as an adsorption inhibitor. The reason for the high efficiency of the inhibitor may be due to the nitrogen atom in TMP2I molecule ${ }^{12,13}$.

\section{Influence of temperature on TMP2I corrosion in $0.5 \mathrm{M} \mathrm{H}_{2} \mathrm{SO}_{4}$ and $1 \mathrm{M} \mathrm{HCl}$}

The influence of temperature on the corrosion behaviour of steel at various concentrations is investigated in the temperature range $303-343 \mathrm{~K}$. The variation of inhibition efficiency with temperature in both the acid media is as shown in the Figure 3.
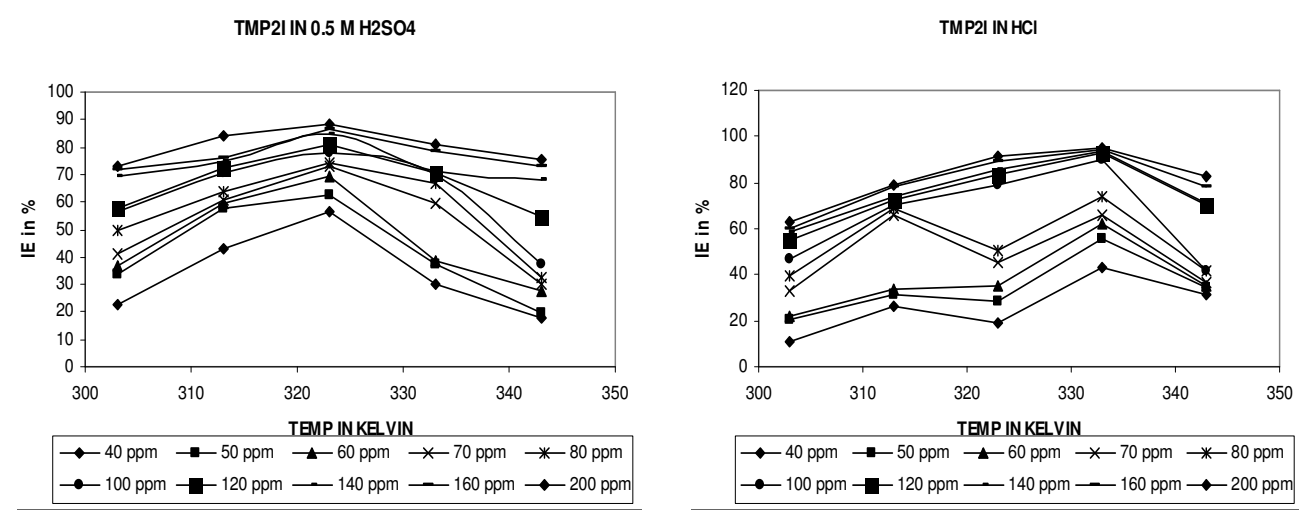

Figure 3. Effect of temperature on the inhibitor efficiency of TMP2I in acid media

From the Figure it can be deduced that an increase in the temperature range of 303-343 K enhanced the IE of the inhibitor up to $333 \mathrm{~K}$ in $\mathrm{HCl}$ medium and $313 \mathrm{~K}$ in sulphuric acid medium.

The behaviour of TMP2I at $303 \mathrm{~K}$ may be attributed to the adsorption of the inhibitor up to $313 \mathrm{~K}$ and after that further increase in temperature brings about desorption of the TMP2I understudy. This may be explained as follows. Adsorption and desorption of inhibitor molecules continuously occur at the metal surface and the equilibrium exists between theses two processes at a particular temperature, with the increase of temperature, the equilibrium between adsorption and desorption process is shifted leading to a higher desorption rate than adsorption until equilibrium is again established at a different value of equilibrium constant. It explains the lower IE at higher temperature ${ }^{14}$.

\section{Adsorption isotherms}

Surface coverage data play an important role in assessment of inhibitor characteristics and are useful for fitting experimental data in to adsorption isotherms which give detailed insight into the inhibition mechanism. TMP2I obeys Langmuir and Temkin adsorption isotherms by giving a straight line for a plot of $\log C$ vs. $\log \theta / 1-\theta$ and $\log C v s . \theta$ respectively. These straight lines obtained reveal that the main process of inhibition is adsorption.

\section{Thermodynamic parameters}

The values of free energy of adsorption were calculated using the standard equation ${ }^{14}$. The results obtained are given in Table 1. 
Table 1. Thermodynamic parameters for mild steel in the presence and absence of TMP2I in $\mathrm{H}_{2} \mathrm{SO}_{4}$ and $\mathrm{HCl}$

\begin{tabular}{|c|c|c|c|c|c|c|c|c|c|c|c|c|c|c|c|c|}
\hline \multirow{3}{*}{$\begin{array}{l}\text { Conc in } \\
\text { ppm }\end{array}$} & \multicolumn{8}{|c|}{$\mathrm{HCl}$} & \multicolumn{8}{|c|}{$\mathrm{H}_{2} \mathrm{SO}_{4}$} \\
\hline & \multicolumn{2}{|l|}{-Ea } & \multicolumn{4}{|c|}{ Change in Free energy } & \multirow[t]{2}{*}{$\begin{array}{c}-\Delta S \\
J / m o l e\end{array}$} & \multirow[t]{2}{*}{$\begin{array}{c}\Delta \mathrm{H} \\
\mathrm{kJ} / \text { mole }\end{array}$} & & \multicolumn{5}{|c|}{ Change in Free energy } & \multirow[t]{2}{*}{$\begin{array}{c}-\Delta \mathrm{S} \\
\mathrm{J} / \mathrm{mole} \\
\end{array}$} & \multirow[t]{2}{*}{$\begin{array}{c}\Delta \mathrm{H} \\
\mathrm{kJ} / \mathrm{mole}\end{array}$} \\
\hline & \multicolumn{2}{|c|}{303} & 313 & 323 & 333 & 343 & & & \multicolumn{2}{|c|}{303} & 313 & 323 & 333 & 343 & & \\
\hline 40 & 43 & 7 & 10 & 9 & 12 & 10 & 87 & 18 & 42 & 9 & 12 & 13 & 10 & 8 & 30 & 20 \\
\hline 50 & 42 & 8 & 10 & 9 & 13 & 11 & 101 & 72 & 46 & 10 & 13 & 13 & 10 & 9 & 50 & 27 \\
\hline 60 & 41 & 8 & 11 & 10 & 14 & 11 & 115 & 14 & 47 & 10 & 12 & 13 & 12 & 9 & 23 & 19 \\
\hline 70 & 48 & 9 & 14 & 10 & 14 & 11 & 90 & 21 & 42 & 10 & 12 & 13 & 13 & 10 & 14 & 38 \\
\hline 80 & 47 & 9 & 14 & 11 & 15 & 11 & 106 & 35 & 44 & 10 & 12 & 13 & 13 & 11 & 24 & 44 \\
\hline 100 & 40 & 10 & 15 & 13 & 18 & 11 & 72 & 25 & 46 & 11 & 12 & 13 & 12 & 9 & 40 & 33 \\
\hline 120 & 40 & 10 & 15 & 11 & 19 & 15 & 13 & 86 & 46 & 11 & 12 & 13 & 12 & 12 & 11 & 41 \\
\hline 140 & 30 & 10 & 15 & 12 & 19 & 15 & 14 & 25 & 47 & 11 & 12 & 13 & 12 & 13 & 32 & 55 \\
\hline 160 & 26 & 9 & 16 & 12 & 20 & 16 & 16 & 66 & 40 & 12 & 12 & 13 & 12 & 14 & 44 & 87 \\
\hline 200 & 22 & 9 & 16 & 12 & 20 & 16 & 18 & 25 & 40 & 12 & 12 & 14 & 12 & 15 & 58 & 88 \\
\hline
\end{tabular}


It was found that the $\Delta \mathrm{G}_{\mathrm{ads}}$ value is less than $-20 \mathrm{~kJ} / \mathrm{mol}$ indicating that the TMP2I are physically adsorbed on the metal surface ${ }^{15-18}$. The negative value of $\Delta \mathrm{G}_{\mathrm{ads}}$ shows a strong interaction of inhibitor molecules and a spontaneous adsorption of inhibitor on the surface of the mild steel ${ }^{16,20}$. Generally values of $\Delta \mathrm{G}_{\mathrm{ads}}$ up to $-20 \mathrm{~kJ} / \mathrm{mol}$ are consistent with electrostatic interaction between charged molecule and a charged metal (which indicates physisorption) while those more negative than $-40 \mathrm{~kJ} / \mathrm{mol}$ involve charge sharing or transfer from the inhibitor molecules to the metal surface to form a coordinate type of bond which indicated Chemisorption $^{19-21}$. Physical adsorption is a result of electrostatic attraction between charged species in the bulk of the solution. The higher values of $\Delta \mathrm{H}$ in the presence of inhibitor indicate higher protection efficiency of the inhibitor. The positive values of $\Delta \mathrm{H}$ suggest that the dissolution process is an exothermic phenomenon and the dissolution of steel is difficult. This means the formation of an ordered stable layer of inhibitor on mild steel ${ }^{22}$. The values of entropy prove strong interaction of the inhibitor on the metal surface ${ }^{23}$.

The Activation energy of the inhibited solution decreases by increasing the concentration of the inhibitor. This finding indicates that TMP2I retards the corrosion of mild steel in both examined media ${ }^{24}$. Thermodynamic parameters for mild steel in the presence and absence of TMP2I are presented in the Table 1.

\section{Tafel polarisation}

Polarisation curves for mild steel in $\mathrm{H}_{2} \mathrm{SO}_{4}$ and $\mathrm{HCl}$ at various concentrations of TMP2I are presented in Figure 4. The values of corrosion current densities $\left(\mathrm{I}_{\text {corr }}\right)$, corrosion potential $\left(\mathrm{E}_{\text {corr }}\right)$, the anodic Tafel slope ba and cathodic tafel slope bc presented in Table 2. The presence of TMP2I does not remarkably shift the corrosion potential $\left(\mathrm{E}_{\mathrm{corr}}\right)$ and hence said to be mixed type of inhibitor.

\section{EIS measurements}

Nyquist plots of mild steel at various concentration of TMP2I in acid media are presented in Figure 5. All the Nyquist plots obtained were in semicircle in nature and the diameter of the semicircles were changed with change in inhibitor concentration. The obtained semicircle cut the real axis at higher and lower frequencies. At higher frequency end, the intercept corresponds to Rs solution resistance and at lower frequency end corresponds to Rs+Rct. The difference between the two values gives Rct, the charge trancsfer resistance. The value of Rct is a measure of the electron transfer across the surface and is inversely proportional to corrosion rate ${ }^{12}$. The semicircle indicates the formation of a barrier on the surface and a charge transfer process mainly controlling the corrosion of mild steel.

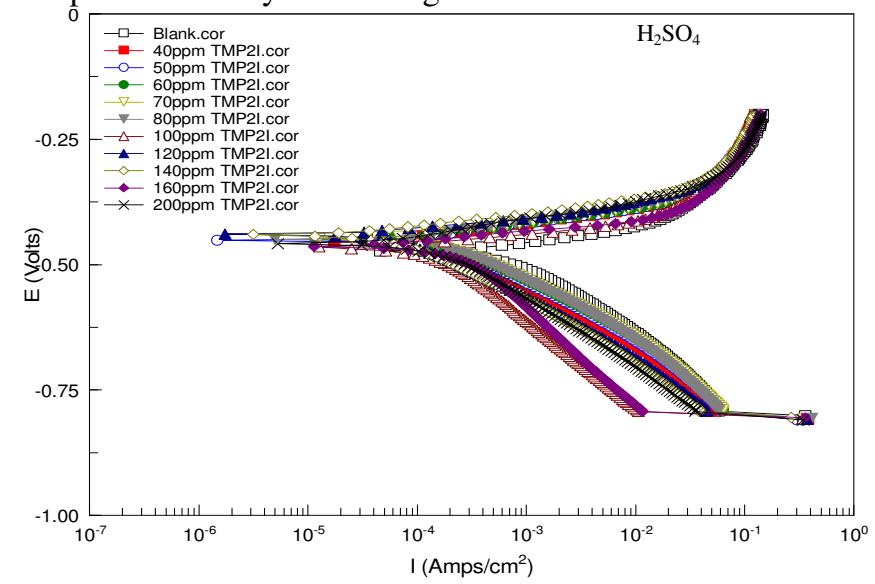




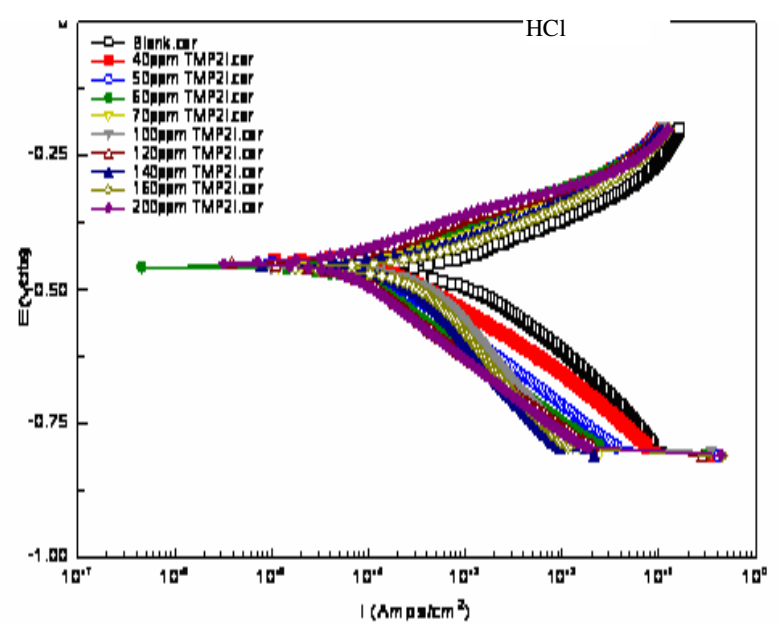

Figure 4. Polarisation curves for mild steel for mild steel in $\mathrm{H}_{2} \mathrm{SO}_{4}$ and $\mathrm{HCl}$

Table 2. Results of polarisation studies of mild steel in the presence of TMP2I in $\mathrm{H}_{2} \mathrm{SO}_{4}$ and $\mathrm{HCl}$

\begin{tabular}{|c|c|c|c|c|c|c|}
\hline \multirow{2}{*}{\multicolumn{2}{|c|}{ Conc of TMP2I in ppm }} & $\begin{array}{r}\mathrm{I}_{\text {corr }} \\
\times 10^{-4} \\
\end{array}$ & $\begin{array}{c}\mathrm{E}_{\text {corr }} \\
\mathrm{mV} / \mathrm{sec}\end{array}$ & $\begin{array}{c}\mathrm{ba} \\
\mathrm{mV} / \mathrm{dec}\end{array}$ & $\begin{array}{c}\mathrm{bc} \\
\mathrm{mV} / \mathrm{dec}\end{array}$ & IE \% \\
\hline & & \multicolumn{5}{|l|}{$\mathrm{mA} / \mathrm{cm} 2$} \\
\hline \multirow{10}{*}{$\mathrm{H}_{2} \mathrm{SO}_{4}$} & Blank & 8.76 & 475 & 73 & 159 & \\
\hline & 40 & 1.96 & 449 & 53 & 110 & 77.62 \\
\hline & 50 & 1.73 & 451 & 52 & 105 & 0.20 \\
\hline & 60 & 1.49 & 456 & 52 & 105 & 82.99 \\
\hline & 70 & 1.24 & 465 & 51 & 129 & 85.80 \\
\hline & 80 & 1.12 & 457 & 50 & 115 & 87.21 \\
\hline & 100 & 1.01 & 451 & 49 & 87 & 88.40 \\
\hline & 120 & 0.72 & 471 & 49 & 116 & 91.70 \\
\hline & 140 & 0.46 & 442 & 44 & 95 & 94.64 \\
\hline & 160 & 0.21 & 453 & 46 & 70 & 97.50 \\
\hline \multirow{11}{*}{$\mathrm{HCl}$} & 200 & 0.21 & 442 & 40 & 74 & 97.51 \\
\hline & Blank & 0.650 & 463 & 79 & 122 & \\
\hline & 40 & 0.568 & 449 & 62 & 140 & 12.60 \\
\hline & 50 & 0.467 & 449 & 64 & 132 & 28.10 \\
\hline & 60 & 0.324 & 457 & 78 & 221 & 50.15 \\
\hline & 70 & 0.289 & 459 & 75 & 224 & 55.5 \\
\hline & 100 & 0.211 & 453 & 71 & 218 & 67.5 \\
\hline & 120 & 0.165 & 455 & 67 & 177 & 74,61 \\
\hline & 140 & 0.112 & 440 & 65 & 104 & 82.76 \\
\hline & 160 & 0.100 & 449 & 68 & 131 & 84.61 \\
\hline & 200 & 0.077 & 456 & 69 & 142 & 88.13 \\
\hline
\end{tabular}



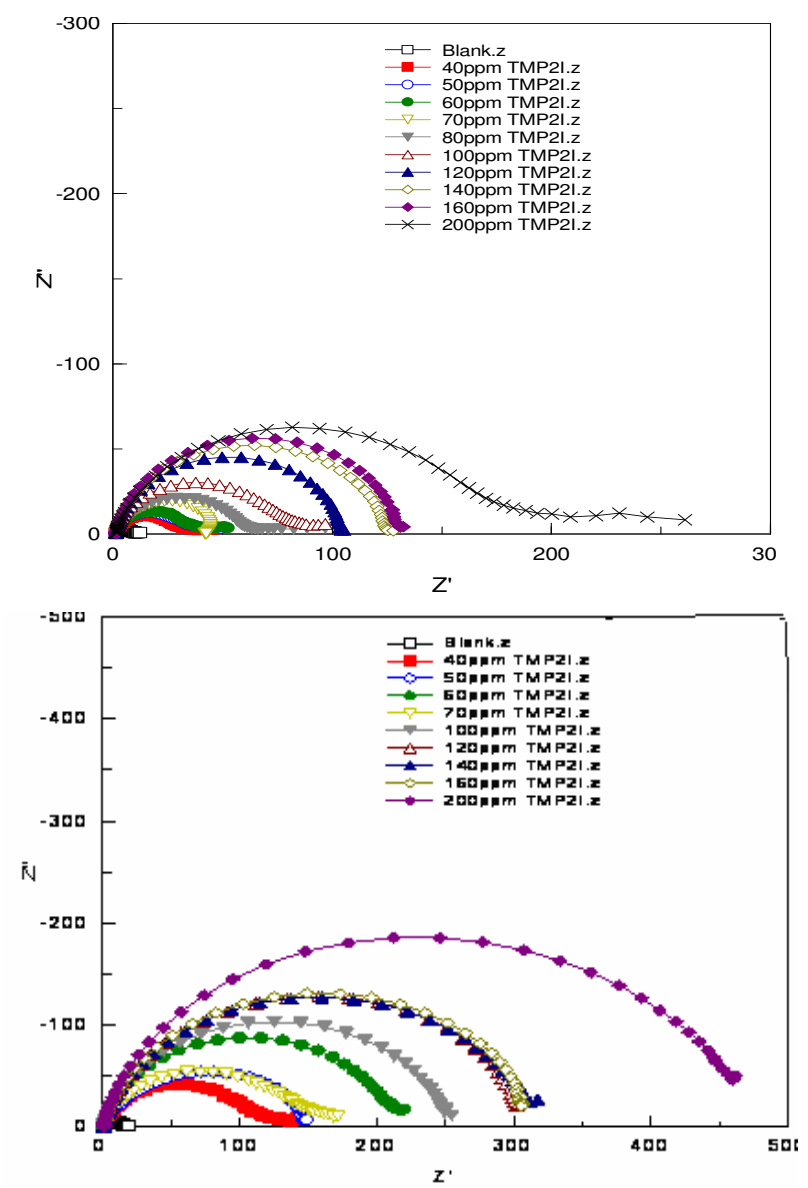

Figure 5. Impedance diagram of mild steel in the presence of TMP2I in acid media

The impedance parameters like Rct, Rp, Cdl and IE are presented in Table 3. The results also show that Rct values increased with increase in increase concentration of the inhibitor. The percentage inhibition calculated form Rct values indicated that TMP2I acts as good inhibitor in both acid media. The Cdl values found to decrease with increase in concentration of inhibitor solutions. This behaviour is generally seen for system where inhibition occurred due to the formation of a layer by the adsorption of inhibitor on the metal surface. The decrease in Cdl value suggest that the inhibitor molecule act by adsorption at the metal solution interface ${ }^{26}$.

\section{Scanning electron microscopic studies}

Figure 6 shows the SEM images of mild steel surface after immersed in $0.5 \mathrm{M} \mathrm{H} 2 \mathrm{SO} 4$ in the absence and presence of TMP2I. Close examination of the SEM images revealed that the specimens immersed in the inhibitor solutions are in better conditions with smooth surfaces compared with those of corroded rough and coarse uneven surfaces of mild steel immersed in $0.5 \mathrm{M} \mathrm{H}_{2} \mathrm{SO}_{4}$ alone. This observation indicated that corrosion rate is reduced to a very low value in the presence of the inhibitors. This might be due to the adsorption of inhibitor molecule on the metal surface as a protective layer ${ }^{26}$. 
Table 3. Corrosion kinetic parameters of mild steel in the presence of TMP2I in $\mathrm{H}_{2} \mathrm{SO}_{4}$ and $\mathrm{HCl}$

\begin{tabular}{|c|c|c|c|c|c|c|c|}
\hline \multicolumn{2}{|c|}{ Conc in ppm } & \multirow{2}{*}{$\begin{array}{c}\begin{array}{c}\mathrm{Rp} \\
\mathrm{ohm} / \mathrm{cm}^{2}\end{array} \\
25.59\end{array}$} & \multirow[t]{2}{*}{ IE \% } & $\begin{array}{c}\text { Rct } \\
\text { ohm } / \mathrm{cm}^{2}\end{array}$ & $\mathrm{IE} \%$ & $\frac{\mathrm{Cdl} \times 10^{-4}}{\mu \mathrm{F} / \mathrm{cm}^{2}}$ & $\Theta$ \\
\hline & Blank & & & 7.94 & & 2.22 & \\
\hline & 40 & 78.13 & 67.24 & 29.92 & 73.45 & 2.43 & 0.094 \\
\hline & 50 & 80.49 & 68.20 & 34.14 & 76.74 & 2.74 & 0.234 \\
\hline & 60 & 82.47 & 68.97 & 34.98 & 77.30 & 3.05 & 0.373 \\
\hline & 70 & 83.42 & 69.32 & 45.67 & 82.61 & 2.88 & 0.297 \\
\hline & 80 & 86.41 & 70.38 & 59.33 & 86.6 & 1.36 & 0.387 \\
\hline & 100 & 88.80 & 71.18 & 77.24 & 89.72 & 1.31 & 0.409 \\
\hline & 120 & 91.24 & 71.95 & 103.57 & 92.33 & 1.21 & 0.423 \\
\hline & 140 & 140.76 & 81.82 & 123.97 & 93.59 & 1.28 & 0.454 \\
\hline & 160 & 175.96 & 85.45 & 129.69 & 93.87 & 0.73 & 0.670 \\
\hline & 200 & 249.41 & 89.73 & 183.26 & 95.66 & 0.66 & 0.892 \\
\hline & Blank & 29.64 & & 13.57 & & 1.97 & \\
\hline & 40 & 2978. & 62.10 & 112.99 & 88.00 & 1.18 & 0.400 \\
\hline & 50 & 88.60 & 66.50 & 147.60 & 90.80 & 0.89 & 0.546 \\
\hline & 60 & 116.01 & 74.40 & 153.27 & 91.11 & 0.80 & 0.590 \\
\hline \multirow[t]{6}{*}{$\mathrm{HCl}$} & 70 & 123.55 & 76.00 & 211.28 & 93.60 & 0.78 & 0.600 \\
\hline & 100 & 140.76 & 78.94 & 250.40 & 94.60 & 0.78 & 0.602 \\
\hline & 120 & 189.08 & 84.32 & 311.37 & 95.65 & 0.69 & 0.647 \\
\hline & 140 & 243.81 & 87.84 & 313.77 & 95.69 & O.68 & 0.653 \\
\hline & 160 & 288.63 & 89.70 & 316.99 & 95.73 & 0.60 & 0.691 \\
\hline & 200 & 359.44 & 91.75 & 461.77 & 97.07 & 0.60 & 0.691 \\
\hline
\end{tabular}

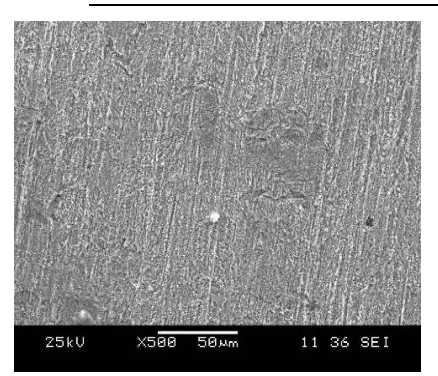

TMP2I

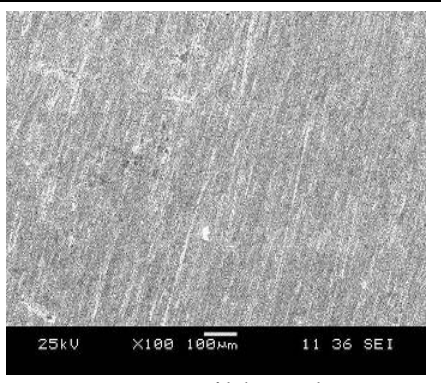

mild steel

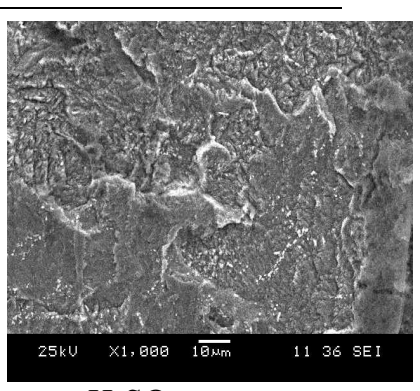

$\mathrm{H}_{2} \mathrm{SO}_{4^{\prime}}$

Figure 6. SEM of TMP2I, mild steel and mild steel dipped in $\mathrm{H}_{2} \mathrm{SO}_{4}$

\section{Conclusion}

TMP2I has been found to be a good inhibitor for mild steel in both the acid media. Inhibition efficiency varies linearly with concentration. The optimum concentration of the inhibitor found is $200 \mathrm{ppm}$. The inhibitor acts as mixed type inhibitor. The results obtained from weight loss, polarization and EMS methods match one another. The inhibitors obey Langmuir adsorption and Temkin adsorption isotherms.

\section{References}

1. Chatterjee P, Benerjee M K and Mukherjee K P, Indian J Technol., 1991, 29, 191.

2. Elachouri. M, Hajji M S, Kertit S, Essassi E M, Salem M and Coudert R, Corros Sci., 1995, 37, 381-389. 
3. Mernari B, Elattari H, Traisnel M, Bentiss F and Larenee M, Corros Sci., 1998, 40, 391.

4. Bentiss F, Traisnel M and Lagrenee M, Corros Sci., 2000, 42, 127-146.

5. Elkadi L, Mernari B, Traisnel M, Bentiss F and Larenee M, Corros Sci., 2000, 42, 703.

6. Elkanouni A, Kertit S and Ben Bachir A, Bull Electrochem.1996, 12, 517.

7. Walker R, Corros Sci., 1975, 31, 97.

8. $\quad$ Kertit S and Hammouti B, Appl Surf Sci., 1996, 93, 59-66.

9. Bentiss F, Traisnel M, Lagrenee M, Hornez J C, Corros Sci., 1999, 41, 789.

10. Lorenz W J and Mansfeld F, Proceedings of the $6^{\text {th }}$ Symposium on European inhibition of Corrosion, University of Ferrara, 1985, 23.

11. Ishihara M and Togo H, Synlett, 2006, 227-230.

12. Stanly Jacob K and Geetha Parameswaran, Corros Sci., 2010, 52, 224-238.

13. Sorkhabi H A, Shaabani B, Seifzadeh D, Electrochem Acta., 2005, 50, 3446-3452.

14. Rawat N S and Singh A K, Bull Electrochem., 1987, 3,7.

15. Quraishi M A and S Khan, Indian J Chem Technol., 2005, 12, 576.

16. Rajalakshmi R, Subhashini S, Leelavathi S and Femina Mary R, Oriental J Chem., 2008, 24(3), 1085.

17. Elachouri M, Hajji M S, Salem M, Kertit S, Aride J, Coudert R and Essasi E, Corrosion, 1996, 52, 103.

18. Savithri B V and Mayanna S, Ind J Chem Tech., 1996, 3, 256.

19. Okafor P C, Ebenso E E, Ibok U J, Ekpe U J and Ikpi M I, Trans SAEST 2003, 38, 91.

20. Talati J D and Daraji J M, J Indian Chem Soc., 1988, 65, 94.

21. Dehri I and Ozcan M, Mater Chem Phys., 2006, 98, 316.

22. Savithri B V and Mayanna S, Indian J Chem Tech., 1996, 3, 256.

23. Abd El-Naby B A, Khamis E, Ramdan M S H and El.Gindy A, $8^{\text {th }}$ European Symposium on Corrosion Inhibitors, Ann.University Ferrara N S, Sez, 1995, 10, 299.

24. Rocca E, Rapin C and Mirambet F, Corro Sci., 2004, 46, 653-665.

25. MaCafferty E and Hackerman N, J Electrochim Soc., 1972, 119, 146.

26. Prabhu R A, Venkatesha T V and Shanbhag A V, J Iran Chem Soc., 2009, 6(2), 353. 


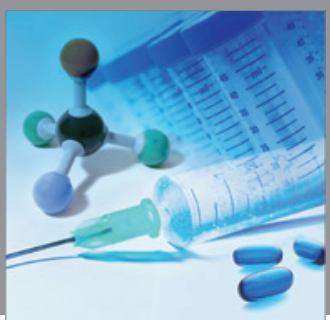

International Journal of

Medicinal Chemistry

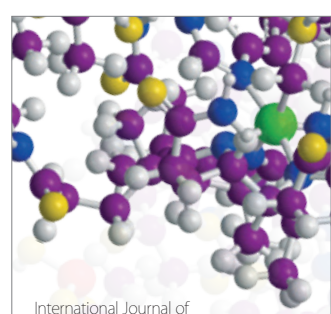

Carbohydrate Chemistry

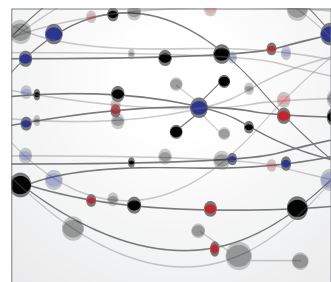

The Scientific World Journal
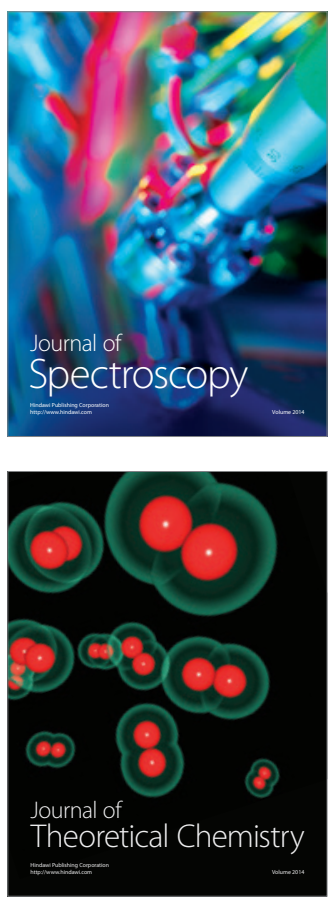
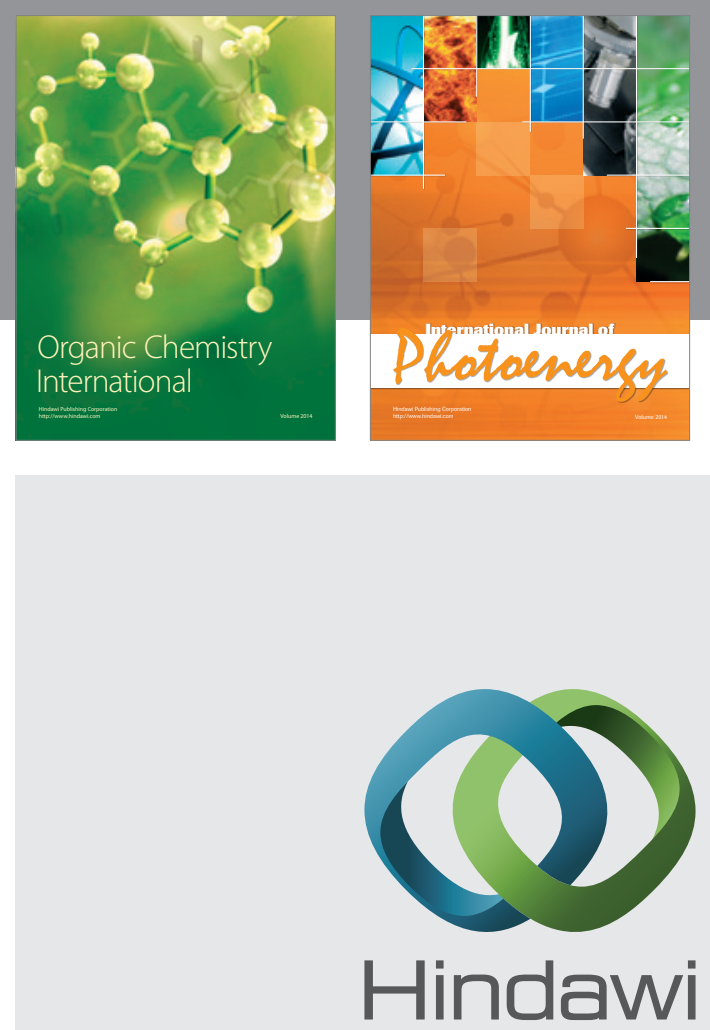

Submit your manuscripts at

http://www.hindawi.com
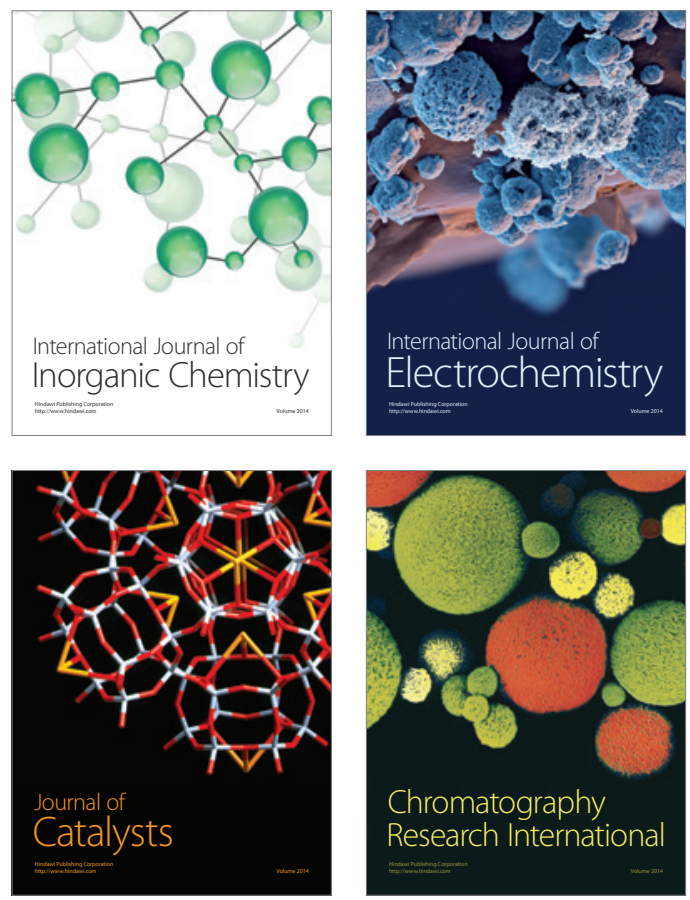
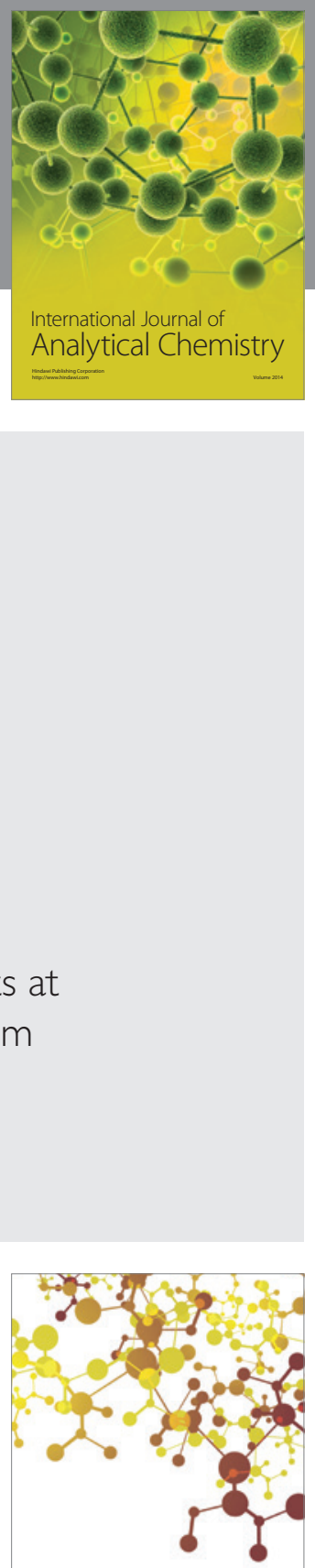

Journal of

Applied Chemistry
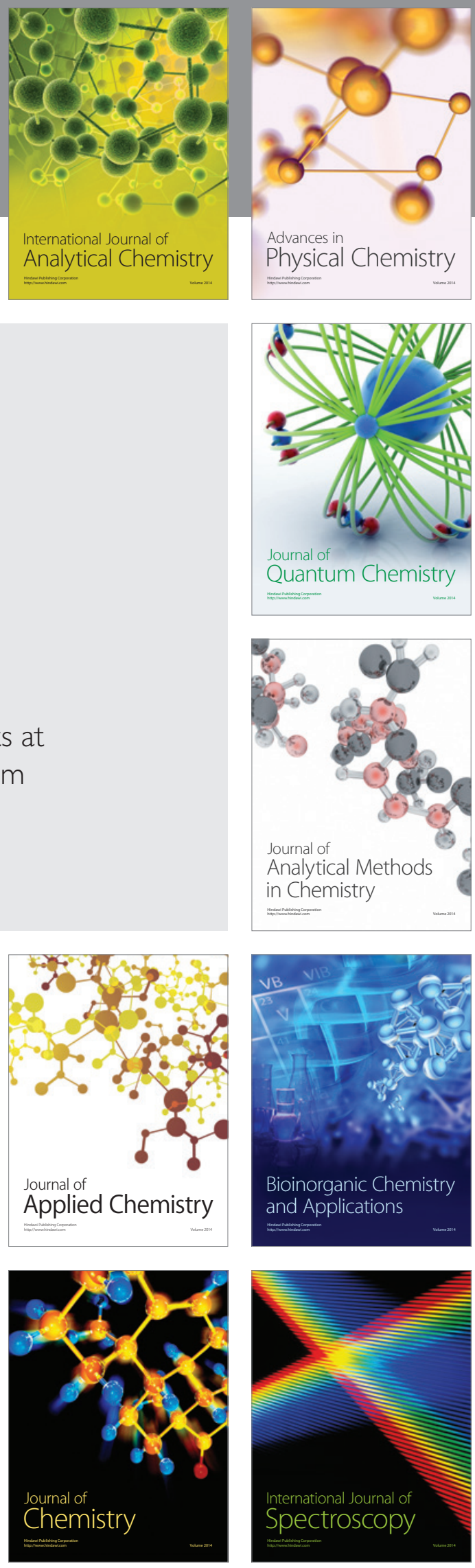